\title{
KARAKTERISTIK LANJUT USIA DENGAN HIPERTENSI DI DESA BANUA BARU
}

\author{
Fredy Akbar K ${ }^{1}$, Syamsidar ${ }^{2}$, Widya Nengsih ${ }^{3}$ \\ ${ }^{1}$ LKS Lanjut Usia Mandar Indonesia \\ ${ }^{2}$ Politekhnik Kesehatan Gorontalo \\ ${ }^{3}$ Akademi Keperawatan YPPP Wonomulyo \\ fredykabira@gmail.com
}

\begin{abstract}
Elderly is someone who moves $>60$ years, both men and women, who are still active in their activities and work both those who are powerless to make their own living so that others need to support themselves. When someone has moved away, continue on about decreasing body power to a certain level that can be done by someone who fixes health problems. One of the diseases that often attacks the elderly is hypertension. Hypertension is a disease caused by an increase in blood pressure. Hypertension can appear without symptoms, while blood pressure that occurs continuously occurs for a long period of time complications can occur.

The purpose of this study was to study the characteristics of hypertension in Banua Baru Village.

This type of research is a descriptive research method. The study was conducted from November 2019 to December 2019. The instrument used was a questionnaire sheet that contained questions about age, sex, occupation, education in the elderly in Banua Baru Village. While the advanced population in Desa Banua Baru is 99 elderly and the sample taken is 24 elderly people.

The results of the study are based on the characteristics of the respondents, namely the most elderly who have hypertension, with age 60-74 (70.8\%), female gender (75\%), IRT work (75\%). While the total of elderly who have hypertension in Banua Baru Village are 24 people.
\end{abstract}

\section{Keywords: Elderly, Hypertension}

\section{PENDAHULUAN}

Proses menua atau aging adalah suatu proses alami pada semua makhluk hidup. Menjadi tua (aging) merupakan proses perubahan biologis secara terus menerus yang dialami manusia pada semua tingkat umur dan waktu. Masa usia lanjut memang masa yang tidak bisa dielakkan oleh siapapun khususnya bagi yang dikaruniai umur panjang, yang bisa dilakukan oleh manusia hanyalah menghambat proses menua agar tidak terlalu cepat, karena pada hakikatnya dalam proses menua terjadi suatu kemunduran atau penurunan(Hannafi, 2014)

Lanjut Usia merupakan kelompok yang paling mudah dan banyak terjangkit masalah kesehatan. Semakin bertambah usia maka semakin menurun kekuatan dan daya tahan tubuh orang tersebut. Penurunan daya tubuh hingga tingkat tertentu dapat mengakibatkan seseorang mengalami masalah kesehatan khususnya pada lansia. (Sutinah \& Maulani, 2017)

Saat ini di seluruh dunia, jumlah lanjut usia diperkirakan lebih dari 625 juta jiwa (satu dari 10 orang berusia lebih dari 60 tahun), pada tahun 2025, lanjut usia akan mencapai 1,2 milyar. Disadari atau tidak, ternyata Indonesia telah memasuki era pertambahan jumlah penduduk lansia, sejak tahun 2000, proporsi penduduk lansia di Indonesia telah mencapai diatas $7 \%$. Pada tahun 2010, jumlah lansia diprediksi naik menjadi $9,58 \%$ dengan usia harapan hidup 67,4 tahun. Prediksi tahun 2020, angka tersebut meningkatmenjadi $11,20 \%$ dengan usia harapan hidup rerata 70,1 tahun. Seseorang dikatakan lanjut usia berdasarkan undang-undang nomor 13/ tahun 1998 adalah mereka yang berumur mencapai 60 tahun keatas (Setiawan, 2016).

Pada usia tersebut lansia mengalami penurunan fungsi imun tubuh fungsi imun tubuh termasuk penurunan fungsi jantung yang salah satu penyakitnya yaitu hipertensi. (Azmi, Karim, \& Annis, 2014)

Hipertensi dikenal secara luas sebagai penyakit kardiovaskular dimana penderita 
memiliki tekanan darah di atas normal. Penyakit ini diperkirakan telah menyebabkan peningkatan angka kematian. Menurut WHO (World HealthOrganization) saat ini terdapat 600 juta penderita hipertensi di seluruh dunia dan 3 juta diantaranya meninggal dunia setiap tahunnya. (Haswan \& Pinatih, 2017)

Hipertensi adalah suatu penyakit yang diakibatkan oleh peningkatan tekanan darah. Hipertensi bisa muncul tanpa gejala, sementara tekanan darah yang terjadi terus-menerus terjadi dalam jangka waktu yang lama dapat mengakibatkan komplikasi. Oleh sebab itu hipertensi perlu di deteksi secara dini dengan pemeriksaan tekanan darah secara berkala. Faktor faktor yang mempengaruhi tekanan darah yaitu usia, jenis kelamin, dan pekerjaan. (Novitaningtyas, 2014)

Penyakit hipertensi dominan terjadi pada perempuan, dimulai usia dari usia diatas 45 tahun, sedangkan laki-laki hanya sebagian kecil yang menderita hipertensi. Alasannya, karena pada perempuan yang belum menopause dilindungi oleh hormon estrogen yang berperan dalam meningkatkan HDL (HighDensity Lipoprotein).kadar HDL rendang atau tinggi mempengaruhi terjadinya proses aterosklerosis dan mengakibatkan peningkatan tekanan darah (Azmi et al., 2014)

Berdasarkan hasil penelitian (Azmi et al., 2014)tentang gambaran kualitas hidup lansia hipertensi didapatkan hasil bahwa mayoritas responden berjenis kelamin perempuan sebanyak 34 orang $(55,7 \%)$. Dalam karakteristik usia hasil penelitian didapatkan hasil sebagian besar responden berada pada usia lanjut yaitu 60-74 tahun sebanyak (83,6\%). Dalam penelitian(Haswan \& Pinatih, 2017)tentang gambaran karakteristik penderita hipertensi diperoleh hasil bahwa berdasarkan jenis kelamin didapatkan sebagian besar responden (56\%) berjenis kelamin perempuan. Berdasarkan kelompok umur, didapatkan hasil sebanyak $80,0 \%$ responden pada kelompok usia $>50$ tahun.

Penelitian ini bertujuan untuk melihat gambaran karakteristik hipertensi pada lanjut usia meliputi usia, jenis kelamin, pekerjaan di desa Banua Baru Hasil penelitian ini diharapkan dapat memberikan tambahan informasi dan referensi dalam peningkatan derajat kesehatan bagi lansia dan dapat mengatasi masalah kesehatan khususnya hipertensi.

\section{METODE PENELITIAN \\ Jenis Penelitian}

Pada penelitian ini menggunakan metode survey dengan pendekatan deskriptif.

\section{Lokasi danWaktuPenelitian}

Penelitian dilakukan mulai bulan November 2019 hingga bulan Desember 2019.

\section{Pengumpulan Data}

Instrumen yang digunakan adalah lembar kuesioner yang meliputi pertanyaan tentang usia, jenis kelamin,pekerjaan pada lanjut usia di Desa Banua Baru.

\section{Populasi danSampel}

Adapun populasi lanjut usia di Desa Banua Baru yaitu 99 lanjut usia dari sampel yang digunakan sebanyak 24 orang lanjut usia yang hipertensi.

\section{HASIL}

Berdasarkan hasil penelitian didapatkan hasil sebagai berikut

Tabel 1. Karakteristik Subjek Penelitian

\begin{tabular}{lcc}
\hline $\begin{array}{c}\text { Karakteristik } \\
\text { responden }\end{array}$ & Jumlah & Presentase \\
\hline Usia & 3 & $12,5 \%$ \\
Pra lansia & 17 & $70,8 \%$ \\
Usia tua & 4 & $16,6 \%$ \\
Usia sangat tua & 24 & $100 \%$ \\
\hline Total & & \\
\hline Jenis kelamin & 6 & $25 \%$ \\
Laki - laki & 18 & $75 \%$ \\
Perempuan & 24 & $100 \%$ \\
\hline Total & 18 & $75 \%$ \\
\hline Pekerjaan & 6 & $25 \%$ \\
Irt & 24 & $100 \%$ \\
\hline Wiraswasta &
\end{tabular}

Tabel 1 di atas menunjukkan distribusi responden berdasarkan karakteristik responden, mayoritas lansia terbanyak yang hipertensi yaitu dengan umur $60-74$ (70,8\%), jenis kelamin perempuan (75\%), pekerjaan IRT (75\%). Adapun total lansia yang hipertensi di Desa Banua Baru yaitu sebanyak 24 orang. 


\section{PEMBAHASAN}

Usia

Berdasarkan hasil penelitian yang dilakukan terhadap 24 orang diketahui bahwa sebagian besar responden berada pada usia lanjut yaitu usia 60-74 tahun sebanyak $(70,8 \%)$.

Semakin tua seseorang maka arteri akan kehilangan elastisitasnya yang menyebabkan kemampuan memompa darah berkurang sehingga tekanan darah meningkat. Sebenarnya wajar apabila tekanan darah meningkat dengan bertambahnya usia karena hal tersebut disebabkan oleh perubahan alami pada jantung, pembuluh darah, dan hormon.(Korneliani\& Meida, 2012)

\section{Jenis Kelamin}

Penelitian yang didapatkan terhadap 24 orang responden mendapatkan hasil bahwa mayoritas responden berjenis kelamin perempuan sebanyak $75 \%$.

Penyakit hipertensi dominan terjadi pada perempuan, dimulai usia dari usia diatas 45 tahun. Alasannya, karena pada perempuan yang belum menopause dilindungi oleh hormon estrogen yang berperan dalam meningkatkan HDL (High Density Lipoprotein). Kadar HDL rendang atau tinggi

\section{DAFTAR PUSTAKA}

Azmi, N., Karim, D., \& Annis, N. F. (2014). Gambaran kualitas hidup lansia dengan hipertensi di wilayah kerja puskesmas sidomulyo kecamatan tampan pekanbaru. Vol 5 no.2, 439-448.

Handayani, D. Sri, Rusli, R., \& Ibrahim, A. (2015). Analisis Karakteristik dan Kejadian Drug Related Problems pada Pasien Hipertensi di Puskesmas Temindung Samarinda. Vol 1. No, 75-81.

Hannafi, A. (2014). Pengaruh Terapi Brain Gym Terhadap Peningkatan Fungsi Kognitif Pada Lanjut Usia Di Posyandu Lanjut Usia Desa Pucangan Kartasura. 1.

Haswan, A., \& Pinatih, G. N. I. (2017). Gambaran Karakteristik Penderita Hipertensi dan Tingkat Kepatuhan Minum Obat di Wilayah Kerja Puskesmas Kintamani I. Intisari Sains Medis, 8(2).

Korneliani, K., \& Meida, D. (2012). Hubungan mempengaruhi terjadinya proses aterosklerosis dan mengakibatkan peningkatan tekanan darah. (Azmi et al., 2014)

\section{Pekerjaan}

Hasil penelitian didapatkan karakteristik responden menurut pekerjaan mayoritas adalah sebagai ibu rumah tangga (IRT) $(75 \%)$.

Pekerjaan sebagai IRT cenderung menyebabkan hipertensi berat karena adanya Stres. Sumber stres dalam pekerjaan meliputi beban kerja, fasilitas kerja yang tidak memadai, peran dalam pekerjaan yang tidak jelas, tanggung jawab yang tidak jelas, masalah dalam hubungan dengan orang lain, tuntutan kerja dan tuntutan keluarga. (Handayani, Rusli, \& Ibrahim, 2015)

\section{KESIMPULAN}

Berdasarkan karakteristik subjek, sebagian besar subjek penelitian termasuk dalam kategori hipertensi yaitu wanita sebanyak $(75 \%)$ dengan usia 60 hingga 74tahun sebanyak $(70,8 \%)$ dengan pekerjaan sebagai Ibu Rumah Tangga (IRT) sebanyak $(75 \%)$

Obesitas dan Stress dengan Kejadian Hipertensi Guru SD Wanita. 7(24), 111115.

Martini, A. (2016). Pengaruh Senam Otak Terhadap Perubahan Daya Ingat (Fungsi Kognitif) Pada Lansia Di Panti Sosial Tresna Werdha Mulia Dharma Kubu Raya. 3(June).

Novitaningtyas, T. (2014). Hubungan karakteristik (umur, jenis kelamin, tingkat pendidikan) dan aktivitas fisik dengan tekanan darah pada lansia di kelurahan makamhaji kecamatan kartasura kabupaten sukoharjo naskah.

Sutinah, S., \& Maulani, M. (2017). Hubungan pendidikan, jenis kelamin dan status perkawinan dengan depresi pada lansia. Jurnal endurance, 2(2), 209. Https://doi.org/10.22216/jen.v2i2.1931. 